
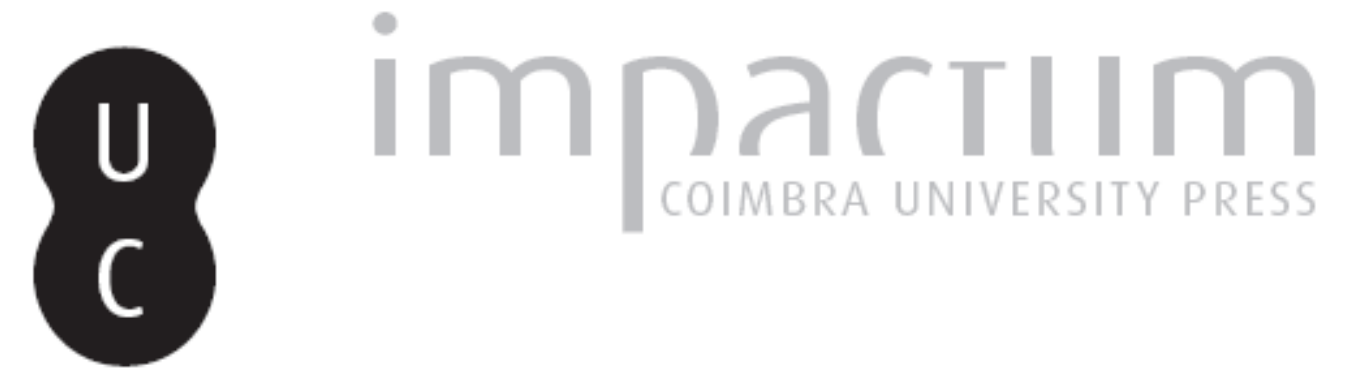

\title{
O fascismo e o salazarismo vistos por Fernando Pessoa
}

\author{
Autor(es): Barreto, José
}

Publicado por: Imprensa da Universidade de Coimbra

URL persistente:

URl:http://hdl.handle.net/10316.2/42431

DOI:

DOl:https://doi.org/10.14195/0870-8584_8_7

Accessed : $\quad$ 26-Apr-2023 14:00:05

A navegação consulta e descarregamento dos títulos inseridos nas Bibliotecas Digitais UC Digitalis, UC Pombalina e UC Impactum, pressupõem a aceitação plena e sem reservas dos Termos e Condições de Uso destas Bibliotecas Digitais, disponíveis em https://digitalis.uc.pt/pt-pt/termos.

Conforme exposto nos referidos Termos e Condições de Uso, o descarregamento de títulos de acesso restrito requer uma licença válida de autorização devendo o utilizador aceder ao(s) documento(s) a partir de um endereço de IP da instituição detentora da supramencionada licença.

Ao utilizador é apenas permitido o descarregamento para uso pessoal, pelo que o emprego do(s) título(s) descarregado(s) para outro fim, designadamente comercial, carece de autorização do respetivo autor ou editor da obra.

Na medida em que todas as obras da UC Digitalis se encontram protegidas pelo Código do Direito de Autor e Direitos Conexos e demais legislação aplicável, toda a cópia, parcial ou total, deste documento, nos casos em que é legalmente admitida, deverá conter ou fazer-se acompanhar por este aviso.

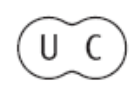




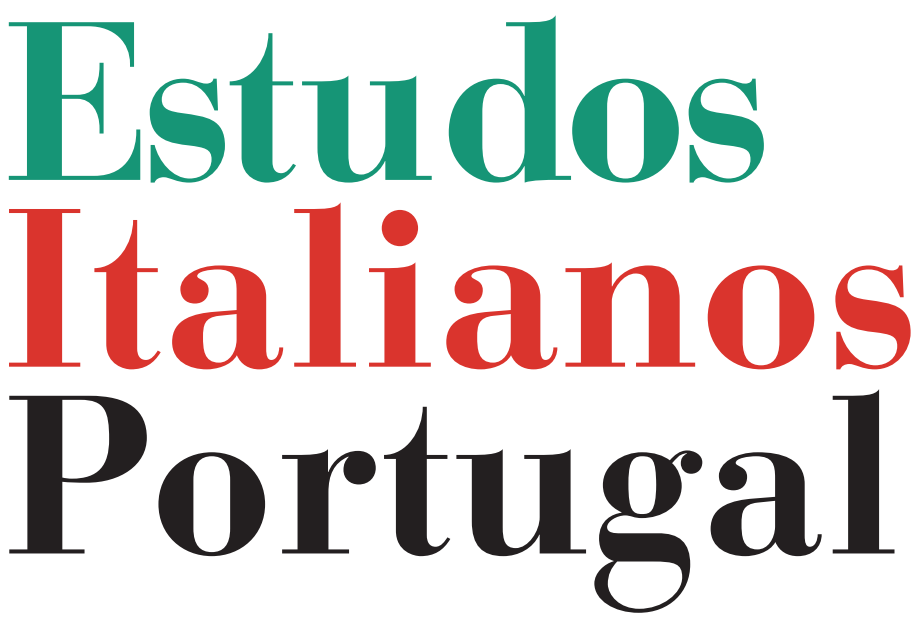

Instituto

Italiano

de Cultura

de Lisboa

Nova Série

$\mathbf{N}^{\circ} \mathbf{8}$ 


\section{O FASCISMO E O SALAZARISMOVISTOS POR FERNANDO PESSOA}

José BARRETo*

PARA ALÉM DAS SUAS FACETAS literárias mais conhecidas, Fernando Pessoa cultivou também, entre outras, a de pensador político, legando à posteridade um impressionante conjunto de textos sobre política e sociedade, escritos da adolescência até à morte, na sua grande maioria deixados inéditos. A grande regularidade com que escreveu sobre tais matérias, contrastando com a raridade da sua publicação, fez com que Joel Serrão se referisse a essa actividade de Pessoa como um "itinerário secreto" e ao produto dela como um "vasto continente submerso" que só esporadicamente emergiu à luz ${ }^{1}$.

Entre a grande variedade de assuntos versados nesses textos políticos e sociológicos, Fernando Pessoa abordou também o tema do fascismo - embora nunca tenha discorrido desenvolvidamente sobre ele, é necessário dizê-lo desde já. Acrescente-se que praticamente ninguém o fez em Portugal nos anos 20 e 30, se descontarmos alguns raros artigos de opinião escritos por publicistas ou tribunos antifascistas, de que Raul Proença é o exemplo mais notável, e também raros artigos e livros de apologia do fascismo, com destaque para os de Francisco Homem Cristo Filho - que foi amigo pessoal

* Instituto de Ciências Sociais, Universidade de Lisboa (ICS-UL).

${ }^{1}$ Joel Serrão, introduções a Pessoa (1979a), p. 19, e a Pessoa (1979b), pp. 9-10 e 13-14. 
de Mussolini - e Martinho Nobre de Mello. Fernando Pessoa deixou, contudo, uma série de pequenos textos sobre o fascismo e outros, sobre diversas matérias, em que abordava de passagem esse tema ou a figura de Mussolini. Foram todos produzidos no espaço de uma dúzia de anos, entre 1923 e 1935, e quase todos ficaram inéditos. Nessa área temáti$\mathrm{ca}$, a sua principal fonte de informação seriam certamente os jornais e revistas ingleses que habitualmente lia, além da imprensa portuguesa e francesa. $\mathrm{Na}$ biblioteca particular de Pessoa, com boa cobertura de temas políticos, não se encontra qualquer obra sobre o tema.

Desde a década de 70 do século XX, Pessoa tem sido considerado por vários estudiosos como um pensador reaccionário e (ou) um defensor de regimes autoritários. Colaram-lhe rótulos diversos, como o de "pré-fascista", "admirador de Mussolini", "ídolo dos nacional-sindicalistas", "antecessor do Estado Novo", etc. Nessa algo insólita empresa de fascistização póstuma do escritor e da sua obra, incluindo a poética, esteve particularmente empenhado o professor, ensaísta e artista Alfredo Margarido, que entre 1971 e 1986 produziu cerca de uma dezena de escritos de carácter jornalístico ou académico sobre as ideias políticas de Pessoa ${ }^{2}$. Diversos autores retomaram depois algumas das apreciaçóes feitas por Margarido. ${ }^{3}$ Inclusive uma figura destacada dos estudos pessoanos como Jacinto Prado Coelho (que esteve ligado à organização do espólio do escritor e à edição de muitos inéditos), embora discordando das teses de Margarido, não deixou também de rotular Pessoa de "reaccionário", exceptuando apenas o período final de vida do escritor, 1934-354. Ora estas avaliações do pensamento político pessoano pecam, em geral, por um

\footnotetext{
${ }^{2}$ Ver alguma da bibliografia de Margarido sobre Fernando Pessoa no final deste artigo.

${ }^{3}$ Ver, por exemplo, Cabral (1983, 2000), Pinto (1996), Morodo (1997) e De Cusatis (2005).

${ }^{4}$ Coelho (1975).
} 
fatal desconhecimento do referido "vasto continente submerso" e, no caso específico de Margarido, por se basearem com frequência em meras especulaçôes ou, como chegou a confessar, em "extrapolações não documentadas". Se milhares de páginas inéditas do espólio de Pessoa eram completamente desconhecidas destes autores até aos anos 80 , sucedia por vezes também que a parte já publicada da obra pessoana dificilmente os autorizaria a fazer alguns dos juízos que fizeram, assentes em análises lacunares ou enviesadas por estereótipos e preconceitos. O propósito comum a esses autores foi, de forma transparente, o de enfileirar Pessoa numa galeria dos escritores e artistas modernistas europeus que teriam preparado o ambiente cultural para o advento dos totalitarismos, aderindo depois a eles ou colocando-se de algum modo ao serviço da "estetização da política" que caracterizou a propaganda dos regimes autoritários. Nesta linha, Margarido foi ao ponto de considerar o livro Mensagem como uma "obra de exaltação nacional-fascista" (sic), produzida no quadro da "colaboração" de Pessoa com a "política do espírito" e as "propostas estéticas" do regime de Salazar5. Facto, porém, é que Pessoa nunca escreveu, pública ou privadamente, uma palavra de elogio do fascismo, perante o qual se manteve sempre muito crítico, desdenhoso e até sarcástico. Também nunca publicou uma palavra em defesa do Estado Novo, embora em alguns escritos privados tenha tecido certos elogios a Salazar, antes de passar sobretudo a desdenhá-lo e, por fim, a atacá-lo com violência e sarcasmo, em prosa e em verso.

Num conhecido apontamento, do qual Margarido também retirou ilações especulativas, Pessoa referia-se à personalidade de Mussolini de um modo alegadamente elogioso: "Plagiamos o fascismo e o hitlerismo, plagiamos claramente, com a desvergonha da inconsciência, como a criança imita sem hesitar. [...] O que não sabemos imitar, porque seria mais

${ }^{5}$ Margarido (1985, 1986). 
difícil, é a personalidade de Mussolini”“. Ora este reconhecimento do carisma do ditador italiano não passava de simples constatação de um facto mais ou menos óbvio, um juízo que nada prova sobre as ideias do seu autor nem sobre a apreciação que ele fazia da política fascista ${ }^{7}$. O intelectual socialista Raul Proença, o primeiro grande opositor português do fascismo, disse sobre Mussolini e os seus imitadores portugueses, num cáustico escrito panfletário de 1926, praticamente o mesmo que Pessoa afirmou no citado apontamento. "Sem massa fascista e sem Mussolini” seria tão difícil fazer um fascismo em Portugal como "fazer pão sem farinha nem levedura" - escreveu Proença em "O fascismo e as suas repercussões em Portugal”, artigo saído na Seara Nova e publicado também em folheto autónomo ${ }^{8}$. Alfredo Margarido não conheceu, infelizmente, outro trecho de Pessoa, datável da década de 20 e igualmente elogioso, se assim lhe podemos chamar, para com Mussolini:

A organização do fascismo é uma obra de talento, mas também não foi um estúpido quem organizou a Mafia ou a Camorra. Há chefes de bandos de assassinos, com grandes qualidades de organização e de coragem; mas a organização e a coragem não convertem os bandos de assassinos em salvadores da civilização, nem o chefe d'eles em benfeitor da humanidade. ${ }^{9}$

É essencial delimitar, no pensamento de Pessoa, a opinião crítica que gradualmente formou sobre a Ditadura Militar e o Estado Novo da opinião constantemente negativa que

${ }^{6} \mathrm{BNP} / \mathrm{E} 3$, 55I-24r, publicado pela primeira vez em Pessoa (1979a), pp. 85-86. Trata-se de um rascunho do artigo "O caso mental português", publicado em Novembro de 1932 no n. 2 da revista Fama.

${ }^{7}$ Diga-se que Pessoa apenas usou, em vários escritos, os termos prestígio e magnetismo pessoal para se referir ao carisma, conceito de origem teológica de que ele provavelmente desconhecia o sentido com que a sociologia política de Max Weber o utilizou, assim como o de autoridade carismática e outros.

${ }^{8}$ Proença (1926).

${ }^{9}$ BNP/E3, 55G-98r, em Fernando Pessoa, Sobre o fascismo, ed. José Barreto, no prelo. 
manteve sobre o fascismo. Refiro-me ao fascismo em geral e, muito em particular, o italiano, não ao "fascismo" português, se assim se pretender designar o regime de Salazar. Nos escritos deixados por Pessoa, o regime autoritário de Salazar só uma única vez aparece referido como fascismo, chamando-lhe mais precisamente, numa nota manuscrita dos anos 30, "the drowsy fascism of Salazar", o fascismo sonolento de Salazar ${ }^{10}$. Num outro escrito de 1935, Pessoa trata derrisoriamente Salazar por "pequeno Duce"11. E é tudo. Pessoa morreu no período inicial do Estado Novo, numa altura em que, à excepção da imprensa clandestina comunista, poucos consideravam fascista a ditadura de Salazar. Além disso, eram bastante raros no Portugal de então os que se assumiam expressamente como fascistas, embora houvesse bastantes admiradores de Mussolini e do seu regime, como também os houve, posteriormente, de Hitler e do nazismo. O efémero movimento dos "camisas azuis", o Nacional-Sindicalismo de Rolão Preto, surgido em 1932-1933 (sobre o qual Pessoa não escreveu uma única palavra), foi o que mais se aproximou da ideologia, dos padrôes organizativos e da simbologia fascista mussoliniana, mas Salazar acabou rapidamente com ele, absorvendo e domesticando boa parte da sua militância (1934-1935). Embora o ditador português admirasse Mussolini e até Hitler, o seu conservadorismo tradicionalista e católico marcava uma distância flagrante em relação ao revolucionarismo de carácter laico ou neopagão do fascismo e do nazismo, que foram ideologias por sua própria natureza concorrentes com a religião tradicional e que, por isso, são hoje apelidadas de "religiōes seculares" ou "religiōes políticas" por historiadores como Emilio Gentile ${ }^{12}$. Note-se, num parêntese, que o catolicismo de Salazar não tornava o ditador mais

\footnotetext{
${ }^{10} \mathrm{BNP} / \mathrm{E} 3$, 92E-58r, em Fernando Pessoa, Sobre o fascismo.

${ }^{11} \mathrm{BNP} / \mathrm{E} 3,92 \mathrm{~V}-88 \mathrm{r}$, de um texto em francês publicado pela primeira vez por Cunha (1987).

${ }^{12}$ Gentile (2006).
} 
atraente para Fernando Pessoa: "O Sr. Oliveira Salazar é, sem dúvida, mais alguma coisa que um financeiro. Infelizmente o que ele é mais é católico, e, de todas as coisas estranhas a uma especialidade, uma religião fechada, dogmática e intolerante é a pior para corrigir os defeitos da especialização" - escreveu por volta de 1932, quando o até então ministro das Finanças se tornou chefe omnipotente do governo ${ }^{13}$.

Pessoa assistiu na sua idade madura, no período pós-Grande Guerra, ao advento das ideologias e dos regimes autoritários na Europa e em Portugal. Distante já do radicalismo republicano da sua juventude e crescentemente céptico da democracia durante a Primeira República, num processo idêntico ao de tantos outros intelectuais seus contemporâneos ${ }^{14}$, Pessoa evoluiu nesses anos para um conservadorismo elitista, de características messiânicas, com o nacionalismo, o anti-socialismo, o anticatolicismo e a defesa do liberalismo económico como traços mais marcantes. Deve notar-se que o nacionalismo místico, cosmopolita e (quase sempre) liberal de Pessoa tinha características bem próprias, que ele virá a distinguir absolutamente do nacionalismo a que chamou "mórbido" ou "animal" que, segundo escreveu, caracterizava o fascismo italiano e o nacional-socialismo alemão e os impelia à agressão e à guerra ${ }^{15}$.

Teoricamente, o advento do fascismo em Itália poderia, a dada altura, ter exercido um decisivo fascínio ou atracção na evolução do pensamento político de Pessoa, como aconteceu com outros intelectuais que, em Portugal e um pouco por toda a Europa, sofreram de imediato essa influência. $\mathrm{O}$ terreno mental do escritor estaria até preparado para isso: com efeito, desde o Ultimatum de Álvaro de Campos (1917) que

\footnotetext{
${ }^{13}$ BNP/E3, 92L-85r, publicado pela primeira vez em Lopes (1993).

${ }^{14}$ Entre os casos mais extremos, citem-se António Sardinha, Francisco Homem Cristo Filho, Alfredo Pimenta e José Soares da Cunha e Costa.

${ }^{15}$ BNP/E3, 26-20r e 92M-62r e 63r, textos incluídos em Fernando Pessoa, Sobre o fascismo.
} 
Pessoa aparentemente deslizava num plano inclinado para o acolhimento de ideologias mitificadoras da força, da autoridade, do Estado e dos chefes ou super-homens salvadores. A crítica da democracia e do liberalismo político que em 19191920, no período mais crítico da Primeira República portuguesa, irrompe na colaboração teórica de Pessoa para o jornal sidonista Acção (artigos "Como organizar Portugal" e "A opinião pública"), bem como o alinhamento do poeta no processo de mitificação póstuma do malogrado "presidente-rei" Sidónio Pais são sinais óbvios de um estádio que poderia ter funcionado como degrau para uma recepção favorável ao fascismo, após a triunfante Marcha sobre Roma. Com Pessoa, todavia, nunca tal se iria verificar, em nenhum momento, como já em 1979 o constatou Joel Serrão, quando organizou a histórica publicação em três volumes de um manancial de textos políticos e sociológicos pessoanos até então desconhe$\operatorname{cidos}^{16}$.

O testemunho mais antigo que no espólio de Fernando Pessoa se pode encontrar relativo ao fascismo italiano é um recorte de um jornal lisboeta, de Fevereiro de 1923, que o escritor datou de sua mão e conservou até à morte. Continha a notícia de uma campanha ordenada em Itália por Mussolini contra a literatura dita imoral, que dera lugar a rusgas de squadristi pelas livrarias e à destruição de livros. A redacção do jornal acrescentava à notícia um apelo para que em Portugal se enveredasse pelo mesmo caminho, mandando-se apreender as obras imorais ou de "forma desbragada", nomeadamente as que enfermavam de um "modernismo patológico", suposta arte raffinée que, afinal, seria muito mais nefasta do que a mera pornografia.

16 Pessoa (1979a, 1979b e 1980). 


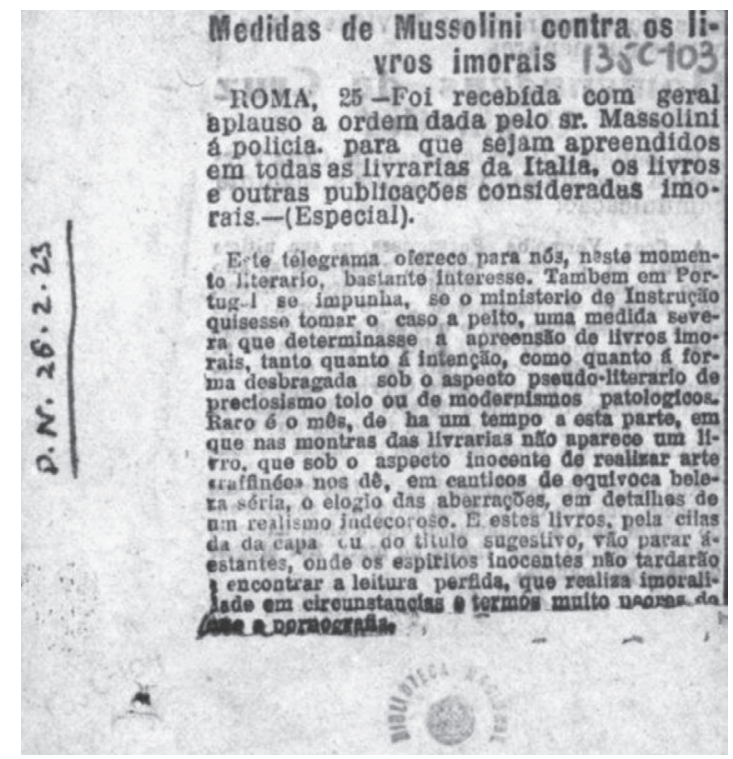

Recorte do Diário de Notícias de 26-2-1923, conservado no espólio de Fernando Pessoa (BNP/E3, 135C-103r).

É bastante plausível que, lendo tal notícia, Pessoa tenha logo formado uma opinião negativa, se não a tinha já, sobre o recém-triunfante fascismo. Mas, dali a poucos dias, a impressão nele causada pelo telegrama de Roma adquiriu certamente outra força. De facto, nos primeiros dias de Março, Pessoa ia assistir em Lisboa a idêntica campanha moralizadora, igualmente com rusgas pelas livrarias, levadas a cabo por estudantes católicos imitadores dos squadristi, e com posterior queima dos livros apreendidos pelas autoridades republicanas. Entre estes incluíam-se dois livros editados pela Olisipo de Fernando Pessoa: as Cançôes de António Botto e Sodoma divinizada de Raul Leal. No espólio de Pessoa há dezenas de páginas de rascunho de um "protesto público" nunca publicado, em que se espelha a repulsa do escritor e editor por aquele acto inquisitorial, por ele explicado como 
um reflexo do que se estava a passar em Itália. O líder da campanha dos estudantes católicos fora Pedro Teotónio Pereira, que passados dez anos entraria para o governo de Salazar. Em 1926, na revista de cariz fascizante Ordem Nova, um jovem Marcelo Caetano ainda evocava elogiosamente a histórica queima "daquela papelada imunda que empestava a cidade", realizada três anos antes ${ }^{17}$.

Esse episódio teve certamente um efeito separador de águas para aquela talvez minoria de artistas e intelectuais portugueses que, como Pessoa, rejeitavam visceralmente o discurso moralista sobre arte e literatura. Todavia, o fascismo não se reduzia a uma orientação ético-estética e outros antídotos tiveram que se conjugar para afastar o autoproclamado antidemocrata Pessoa do trilho quase fatal do autoritarismo ou do totalitarismo.

Por um lado, o fundo liberal da educação britânica de Pessoa, o seu elitismo, antiplebeísmo e individualismo radicais, bem como a sua apologia do capitalismo de mercado livre e da concepção spenceriana de um Estado estritamente limitado ${ }^{18}$ mantiveram-no basicamente afastado e crítico em relação ao fascismo que, como sabemos, nasceu de um movimento de massas e era anti-individualista, estatista, economicamente intervencionista e corporativista. Lidas hoje, muitas das teses pessoanas sobre o papel relativo do Estado e dos indivíduos ou sobre o fascismo, o socialismo e o comunismo aproximam-se flagrantemente das ideias expressas nos anos 40 por Friedrich Hayek e pelos seus seguidores do hoje chamado libertarian movement. Por outro lado, um decisivo antídoto contra as ideias autoritárias e fascistas foi, em Pessoa, a sua defesa intransigente da dignidade da pessoa humana e da liberdade do espírito, a sua constante apologia

\footnotetext{
${ }^{17}$ Caetano (1926). Autoproclamando-se "antidemocrática", "antiliberal”, “intolerante e intransigente", etc., a Ordem Nova dizia-se também "católica, apostólica e romana”.

${ }^{18}$ A este respeito, ver Barreto (2007).
} 
da liberdade de expressão e criação artística individuais, bem como a sua posição sobre o papel independente dos intelectuais na sociedade e perante o Estado. Conjuntamente, estas características levaram-no a reunir o hitlerismo, o fascismo e o bolchevismo sob o mesmo rótulo de sabor apocalíptico: eram "a tripla prole do Anti-Cristo" ${ }^{19}$. Ou, numa abordagem diferente, noutro escrito dos anos 30: "Soviets, comunismo, fascismo, nacional-socialismo - tudo isso é o mesmo facto, o predomínio da espécie, isto é, dos baixos instintos, que são de todos, contra a inteligência, que é do individuo só" 20 . $\mathrm{Ou}$, ainda, num escrito de cerca de 1925, quando ainda não se falava de Hitler: "Seguimos o princípio contrário ao do tio Mussolini e ao do abade Lenine. Desoprimir! Tornar os outros diferentes do que nós queremos! Ensinar cada homem a pensar pela sua cabeça e a existir com a sua existência - só com a sua existência" aqui um outro escrito pessoano de 1925, em que troçava do conteúdo de uma carta enviada pelo Duce ao Times ${ }^{22}$. Outra ideia curiosa de Pessoa, exposta numa carta de 1931 a João Gaspar Simões - ideia que mais tarde faria escola entre os historiadores dos regimes totalitários e das "religiōes políticas" - era a de que tanto o comunismo como o fascismo eram "seitas religiosas de misticismo político"23.

Os textos e trechos que Pessoa escreveu ao longo de uma dúzia de anos sobre o fascismo e Mussolini não obedeciam, em geral, a qualquer plano, parecendo por vezes surgir ao sabor de leituras de jornais ou conversas de café. Outros aparecem no meio de divagações quer sobre temas afins, como o nacionalismo e as ditaduras, quer sobre assuntos só remotamente relacionáveis, como o conceito de "civilização mate-

\footnotetext{
${ }^{19}$ Carta ao jornal $A$ Voz de 28-1-1934, publicada pela primeira vez em Lopes (1993).

${ }^{20}$ BNP/E3, 55B-5r, em Fernando Pessoa, Sobre o fascismo.

${ }^{21} \mathrm{BNP} / \mathrm{E} 3$, 92E-64r, em Fernando Pessoa, Sobre o fascismo.

${ }^{22} \mathrm{BNP} / \mathrm{E} 3$, 92A-4r, publicado pela primeira vez em Pessoa (1979b).

${ }^{23}$ Martines (1998), p. 174.
} 
rial", a suposta "conspiração dos Trezentos" ou o "problema mental português". Apenas quatro ou cinco desses textos parecem ter sido escritos a pensar na sua publicação imediata, mas só uma única vez chegaram a ver a luz do dia, ainda que anonimamente.

Nesses escritos, por regra fragmentares, podemos surpreender o conservador liberal de estilo inglês (assim se definiu a si próprio) a manifestar o seu desprezo pela estridência do fascismo: "O fascismo é o simulacro estridente das doutrinas chamadas da contra-revolução, que, elas, são a voz alta de coisa nenhuma" 24 . Outras vezes vemos o leitor de obras de psicologia e psiquiatria a diagnosticar o primitivismo mental, a morbidez, a loucura e a paranóia dos fascistas, como antes rotulara similarmente os anarquistas e outras espécies de revolucionários. Em vários escritos, fascismo e hitlerismo (não se usava ainda o termo nazismo) são amalgamados por Pessoa ao bolchevismo ou comunismo, vistos assim como faces diversas de um mesmo fenómeno "animal" e "baixamente instintivo", que em todo o mundo ameaçava o indivíduo, a inteligência, a liberdade do espírito e, consequentemente, a civilização. Não se encontra, obviamente, qualquer observação do sociólogo Pessoa sobre uma eventual relação do fascismo com o sistema capitalista e as suas convulsões cíclicas, nem mesmo com as causas políticas da crise da democracia na Europa do pós-guerra. Para Pessoa, as raízes do fascismo ligavam-se preferencialmente a causas de patologia social e psicossocial, a factores espirituais e culturais ou a conspirações conduzidas na sombra por forças ocultas, mancomunadas entre si mesmo quando politicamente se situavam no extremo oposto umas das outras. Pessoa acreditava que fascistas e bolchevistas se irmanavam num ataque comum à civilização.

\footnotetext{
${ }^{24}$ BNP/E3, 26-61, em Fernando Pessoa, Sobre o fascismo.
} 
Podemos também surpreender Pessoa a usar do seu sarcasmo mais destruidor para com o fascismo, como no seguinte texto dos anos 20, que é a resposta a um frequente argumento em favor do fascismo, a saber, que os comboios andavam finalmente à tabela em Itália:

A obra principal do fascismo é o aperfeiçoamento e organização do sistema ferroviário. Os comboios agora andam bem e chegam sempre à tabela. Por exemplo, você vive em Milão; seu pai vive em Roma. Os fascistas matam seu pai mas você tem a certeza que, metendo-se no comboio, chega a tempo para o enterro. ${ }^{25}$

Em Novembro de 1926 dá-se o episódio da entrevista forjada por Pessoa, publicada no diário Sol, com um imaginário exilado antifascista de nome Giovanni B. Angioletti, nome de um intelectual italiano bem real, que nada teve a ver com o caso nem nunca residiu em Portugal ${ }^{26}$. A Ditadura Militar que antecedeu o Estado Novo tinha então seis meses de existência e estava longe de se definir claramente do ponto de vista político. Alguns dos chefes militares simpatizavam com a noção de "regime de autoridade" e, consequentemente, com o modelo que o fascismo italiano, então já totalmente radicalizado, lhes proporcionava. $\mathrm{O}$ director do efémero diário lisboeta Sol, Celestino Soares - um jovem e brilhante amigo de Pessoa que o tinha convidado para uma colaboração multiforme para esse jornal, incluindo artigos, poesias, a dita entrevista e até a tradução de um romance policial em folhetins -, era um republicano do Partido Democrático, o partido afastado do poder pelo golpe dos militares, e um crítico acerbo do fascismo. Na sua curtíssima existência, o Sol inseriu vários artigos denunciando violências fascistas em Itália e também movimentações de milícias e elementos filo-fascistas portugueses. $\mathrm{Na}$ terceira semana de Novem-

\footnotetext{
${ }^{25}$ BNP/E3, 133E-12r, em Fernando Pessoa, Sobre o fascismo.

${ }^{26}$ Este episódio é relatado em pormenor por Barreto (2012a).
} 
bro de 1926 encontrava-se em Lisboa um hierarca fascista, o deputado e coronel dos camisas negras Ezio Maria Gray (membro do Grande Conselho do Fascismo em 1924-25), que se deslocara à capital portuguesa para fundar o fascio dos italianos ali residentes. Foi precisamente nesse momento que Fernando Pessoa redigiu a sua entrevista imaginária com o suposto exilado Angioletti, o que lhe permitiu expressar, por interposto "grande intelectual italiano", algumas opiniões suas sobre o fascismo e sobre Mussolini. O episódio foi, directamente, uma reacção à criação do fascio de Lisboa e à presença de Ezio Gray entre nós. Indirectamente, foi uma reacção ao contexto de crescente influência ideológica do fascismo em Portugal, na sequência do golpe militar de Maio de 1926.

Esse facto não significou, de modo algum, que Pessoa se tivesse aproximado da resistência republicana e democrática - que não estava ainda organizada - ou, sequer, que se opusesse à Ditadura Miliar vigente. Pessoa apenas aceitou o desafio do seu amigo, agarrando a oportunidade de escrever para um diário, expor algumas das suas ideias sob uma falsa identidade e, naturalmente, ser pago pela sua colaboração. A ideia da entrevista forjada com o suposto Angioletti nasceu plausivelmente de uma conversa com Celestino Soares, dado o ulterior plano de Pessoa de incluir essa pseudo-entrevista numa colectânea de textos escritos por "solicitação externa", sob o imaginado título Episódios. Certamente que Soares conhecia a opinião de Pessoa sobre o fascismo, considerando-o um fenómeno de loucura colectiva e contagiosa, um nacionalismo estreito, passadista e uma traição à missão civilizacional e universalista da Itália, bem como sobre Mussolini, que Pessoa considerava um génio político, mas simultaneamente um "louco paranóico" e um "primitivo cerebral". 


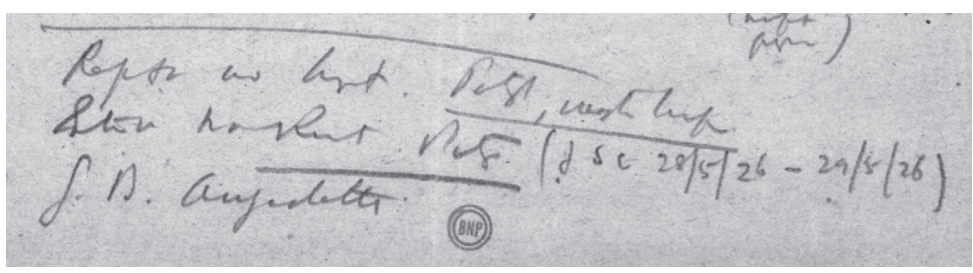

Fragmento de uma lista de obras publicadas por Fernando Pessoa, elaborada pelo autor em 1928 e contendo o nome de G. B. Angioletti (BNP/E3, 189r).

Como se disse já, em Novembro de 1926 nada ainda estava definido quanto ao rumo político que a Ditadura Militar portuguesa ia tomar. Até 1930, data em que Salazar consolida o seu poder no governo e dá maior coesão política à Ditadura, houve muitas indecisões, provas de força e ajustes de contas entre os próprios chefes militares. Só em 1932 é que Salazar é nomeado primeiro-ministro e assume formalmente as rédeas do poder ditatorial, o que não evitou que até 1935 , já com a Constituição do Estado Novo entretanto aprovada, continuasse a haver tentativas de golpe por parte das oposições. Pouco antes da sua morte em Novembro de 1935, Pessoa escreveu um longo texto em francês sobre Salazar em que exprimia fortes dúvidas sobre a durabilidade do ditador, muito longe de imaginar que este permaneceria no poder por mais 33 anos $^{27}$.

Em 1926, Pessoa estava na expectativa, muito atento ao que se passava em Portugal e na Europa, observando tudo com o seu implacável espírito crítico e a sua teimosa independência. Sabemos que detestava a censura instaurada pelos militares, sobre a qual compôs em 1927 um poema satírico ${ }^{28}$. Sabemos também que o nacionalista Pessoa se opunha visceralmente à adopção de modelos políticos estrangeiros. Não

\footnotetext{
${ }^{27}$ Publicado pela primeira vez em Cunha (1987).

28 "Fado da Censura", publicado pela primeira vez em Pessoa (2006), pp. 470-471.
} 
rejeitava apenas o internacionalismo da esquerda, desprezava igualmente a influência de Charles Maurras na génese do Integralismo Lusitano (movimento da direita nacionalista, monárquica, católica e corporativista) e as ridículas imitações do mussolinismo e do hitlerismo que foram surgindo no panorama português, nomeadamente em torno da figura do comandante Filomeno da Câmara, chefe de várias intentonas fascizantes, inclusive uma, em 1927, contra a própria Ditadura Militar. Em 1932, num trecho sobre o provincianismo português, Pessoa renovava a sua queixa recorrente sobre esses plágios:

Surgiram amálgamas frustes de teorias estrangeiras, na sua maioria, quando não totalidade, suspeitas à inteligência e repugnantes ao instinto. E ainda os amálgamas são o menos. O mais tem sido plágio directo, sem confusão nem mistura. Plagiou-se quanto havia lá fora para plagiar - coisas que venceram, pelo menos temporariamente, como o fascismo; coisas que estão para vencer ou não vencer, como o hitlerismo. Ninguém pensou se esses sistemas, suspeitos em si mesmos, tinham qualquer dificuldade em ser aplicados a Portugal. ${ }^{29}$

Pessoa tinha sido surpreendido pelo golpe militar de 28 de Maio de 1926, que considerou injustificado: "A ditadura militar portuguesa surgiu na paisagem política da nação de um modo inesperado, como um comboio onde não há linha”, escreveu por volta de 1929-30, num fragmento até hoje inédito $^{30}$. De facto, sabemos que em 1926 não havia já em Portugal um clima de desordem social, com greves violentas e atentados à bomba, nem qualquer ameaça revolucionária anarquista ou comunista, como fora o caso em 1918 e nos dois ou três anos agitados que se seguiram à Grande Guerra. $\mathrm{Na}$ opinião de Pessoa, expressa no mesmo escrito, a Ditadura Militar derrubara um governo (do Partido Democrático)

\footnotetext{
${ }^{29} \mathrm{BNP} / \mathrm{E} 3,92 \mathrm{M}-60 \mathrm{v}$, em Fernando Pessoa, Sobre o fascismo.

${ }^{30} \mathrm{BNP} / \mathrm{E} 3,92-59 \mathrm{r}$.
} 
que "não havia desmerecido flagrantemente da confiança do país". A ditadura portuguesa fora instaurada apenas por uma razão, "que não é razão alguma": imitar a ditadura de Primo de Rivera em Espanha ${ }^{31}$. O golpe militar de 1926 repôs na ordem do dia também a questão da forma de governo, República ou Monarquia. Entre os principais militares golpistas, alguns pretendiam a restauração monárquica, mas os militares republicanos eram mais numerosos e agrupavam-se em torno do líder da Ditadura Militar, o general Carmona (presidente da República de 1928 até à sua morte em 1951). Diversos escritos provam que Pessoa tomou decididamente o partido da manutenção da forma republicana e nessa posição se manteve até ao fim da vida, embora teoricamente considerasse a Monarquia como o regime "natural" para um império colonial como Portugal. Já no seu panfleto $O$ Interregno (1927-28), Pessoa alegava que a "metade" republicana da nação portuguesa era maior e mais coesa do que a "metade" monárquica.

Repita-se que não havia um "regime português" quando, em 1927-1928, Pessoa escreveu e publicou O Interregno, obra geralmente apontada quando se pretende demonstrar que o autor defendia um regime autoritário. Não havia um regime, mas apenas uma ditadura que não se sabia exactamente para onde ia, nem os seus próprios dirigentes o sabiam. As várias facções da Ditadura Militar, que não paravam de medir forças entre si, só concordavam num ponto: o país não podia voltar à velha República, onde o poder fora monopolizado pelo Partido Democrático e em que nunca emergira uma consistente alternativa de governo a esse partido. Mas um sector militar queria o regresso, a prazo, à normalidade constitucional republicana, outros, os chamados nacionalistas, queriam fazer tábua rasa do passado e enveredar por um regime de autoridade, outros, enfim, tinham a restauração da 
Monarquia como objectivo primário, com ou sem governo autoritário. Vivia-se uma fase transitória para algo desconhecido. A essa realidade chamou Pessoa "Estado de transição" ou "Interregno". Mas que propunha ele afinal no seu panfleto $O$ Interregno, em que o discurso crítico e racional do sociólogo dava as mãos ao discurso místico e hermético do poeta-profeta? Nunca o saberemos, porque ele nunca o explicou. O Interregno foi apenas o primeiro de uma série de cinco manifestos que pretendia publicar, mas nunca escreveu, ficando-se pelo primeiro. Apenas podemos ter a certeza de que não advogava nem o regresso ao constitucionalismo (republicano ou monárquico), nem a instauração de um regime de autoridade (à italiana ou outro), nem a restauração da Monarquia sob qualquer figurino - ou seja, as três hipóteses principais que estavam em cima da mesa da Ditadura Militar.

$O$ impacto do manifesto $O$ Interregno foi escasso, praticamente nulo, o que explicará em parte o facto de Pessoa ter desistido de o completar ${ }^{32}$. $\mathrm{Na}$ sua primeira versão de folha volante anónima (publicada em nome de um obscuro e amplamente inexistente Núcleo de Acção Nacional), o manifesto tinha sido proibido pela censura militar - facto ainda hoje ignorado. Só a intervenção do então ministro do Interior, Vicente de Freitas, um general republicano e dado como "pró-liberal", que seria posteriormente afastado do poder por Salazar, tornou possível contornar a decisão da censura de proibir a publicação do manifesto de Pessoa. $\mathrm{O}$ texto teve de ser modificado pelo autor, que foi obrigado a assumir pessoalmente a sua autoria e a publicá-lo sob a forma de livro, única forma de escapar à censura. Os censores militares obviamente não gostaram do tom livre de Pessoa, que se gabava algo arrogantemente de ser o primeiro português, entre políticos e não políticos (militares incluídos), a falar de modo "nacional" e "superior" ao país. Além disso, Pessoa

\footnotetext{
${ }^{32}$ Sobre $O$ Interregno e o contexto político da sua publicação, ver Barreto (2012b).
} 
afirmava provocatoriamente que $O$ Interregno não visava defender "os actos particulares da Ditadura Militar presente" e que, se esta viesse a cair, defenderia outra Ditadura Militar. Para cúmulo, o único autor referido ao longo do manifesto e nele abundantemente citado, era Lord Hugh Cecil, um político conservador inglês, amigo de Churchill, que publicara o clássico Conservatism, um dos livros de cabeceira de Pessoa. Para os militares nacionalistas, Lord Cecil, ainda que conservador, era simplesmente um "político", termo com péssima conotação para eles, e ainda por cima inglês, não nacional.

Mais graves, do ponto de vista dos censores militares, eram certamente algumas das teses que Pessoa desenvolvia no seu panfleto, quando acaso descia das alturas da sua argumentação teórica. Assim, na opinião do autor, o regime a criar pelo Estado de transição (ou Interregno) não podia ser duradouramente um governo "tipicamente de força”, que só existiria em sociedades bárbaras e semibárbaras. A um governo tipicamente de força, só necessário numa revolução ou numa guerra civil, teria de suceder, por um processo de consolidação e estabilização, um "governo de autoridade". Mas também este, segundo Pessoa, não poderia durar para sempre, pois que a autoridade seria um "prestígio ilógico", logo sujeito, com o tempo, a degenerar e a desaparecer. Quando $O$ Interregno foi publicado, em Março de 1928, o "governo de autoridade" da Ditadura Militar durava já há quase dois anos. O que Pessoa explica no seu panfleto - e que os censores militares perfeitamente entenderam - é que esse governo de autoridade não podia durar muito mais, havendo a necessidade de o transformar num "sistema de governo fundado na opinião", pois além da força e da autoridade não restaria outro fundamento para a existência de um governo, senão a opiniāo. A solução consistiria, pois, em extrair da opiniāo pública um sistema de governo, o que Pessoa, note-se, nunca explicou como se faria. $\mathrm{E}$, apesar da verve antidemocrática que $O$ Interregno também contém, Pessoa sabia bem (e escreveu-o num rascunho para 
essa obra) que um governo fundado na opinião teria que ser sempre uma espécie de democracia - embora não aquela que Portugal e os países europeus conheciam. Observe-se que várias destas ideias, expressas por Pessoa desde a década de 10, se aproximavam, avant la lettre, das do movimento Renovação Democrática, efémera associação política de intelectuais que em 1932 se formaria no Porto e em Lisboa ${ }^{33}$.

Em 1935, com a imprensa já totalmente controlada por uma censura férrea, Pessoa pretendeu tomar uma posição pública contra a invasão italiana da Etiópia. Um artigo pronto e assinado em que satirizava o militarismo e o imperialismo da Itália fascista, contrapondo-lhes as posições antimilitaristas e anti-imperialistas que Mussolini defendera no passado, quando era socialista, foi muito plausivelmente proibido pela censura do Estado Novo em fins de Outubro de $1935^{34}$. Outro artigo que Pessoa começara a escrever em Outubro e que projectava publicar na imprensa lisboeta, em que atacava a agressão de Mussolini ao país africano, desmontando a argumentação anti-escravatura com que a Itália pretendera justificá-la na Sociedade das Nações, ficou inacabado, talvez por saber de antemão que iria ser cortado pela censura. Nesse texto, Pessoa não se limitava a condenar o acto imperialista e a refutar todas as suas justificações, pois associava-o à própria natureza do fascismo ${ }^{35}$. Pessoa começara por escrever, em Setembro desse ano, um poema satírico sobre o mesmo tema, que também ficou inédito:

${ }^{33}$ Um dos seus promotores foi Pedro Veiga, que mais tarde sublinhará as afinidades entre as ideias políticas de Pessoa e as da Renovação Democrática (Veiga, 1982).

${ }^{4}$ Profecia italiana, publicado pela primeira vez em Cunha (1985), meio século depois de escrito.

${ }^{35}$ Sobre estes dois artigos de Pessoa, ver Barreto (2009). 
Dizem que vão apresentar

na Sociedade das Nações

um livro feito pra provar

(não sei se em forma clara ou escura)

que os abexins não têm razões

pois na Abissínia há escravatura.

Se isto é feito a favor da Itália,

é argumento que não dura

o tempo que uma criatura

leva a esfolhar a dália:

na Itália fasce a escravatura.

$\mathrm{Na}$ Itália tudo é escravatura. ${ }^{36}$

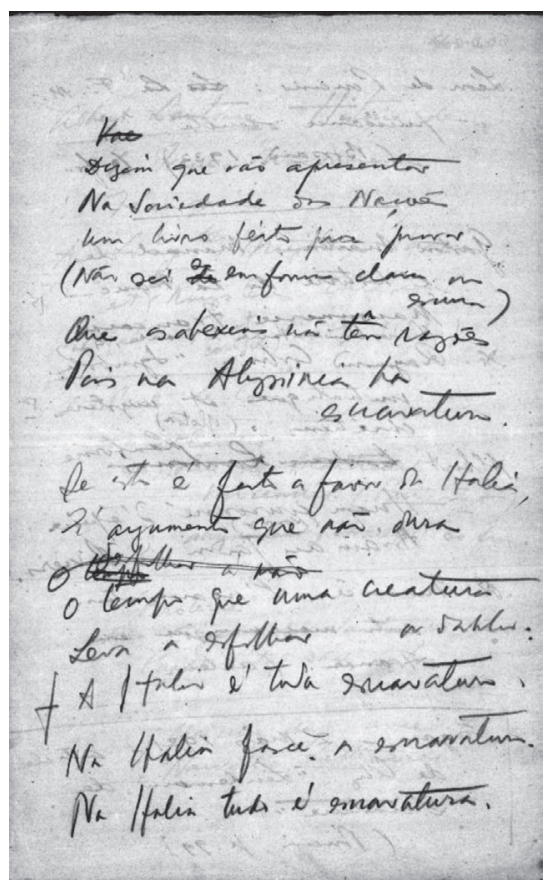

Original manuscrito do poema.

${ }^{36}$ BNP/E3, 66D-25av, publicado pela primeira vez em Pessoa (2006), pp. 543-544. Agradeço a Luís Prista a ajuda prestada na fixação que aqui se propõe do texto do poema. 
O caso de Pessoa ilustra bem o progressivo descontentamento de um sector dos intelectuais portugueses com o salazarismo. Vários escritos que deixou impublicados - e que nunca poderiam ter passado pela censura - expõem de forma clara esse processo. E oportuno citar aqui um deles, redigido em inglês e até hoje inédito, pois traça um paralelo entre a situação italiana e a portuguesa:

In Italy the intellectuals were against the fascist system from the outset. It was clearly a tyranny from the outset. In Portugal, the intellectuals which at first were either politically indifferent or even favourably disposed to the Dictatorship, have gradually been pushed and pressed into the opposition. No intellectual of any real standing, that is to say, of any standing which is both moral and intellectual, lives now in the shade of the drowsy fascism of Salazar. ${ }^{37}$

Pessoa foi talvez um desses "indiferentes ou mesmo favoravelmente dispostos para com a ditadura" que, nunca tendo aderido realmente ao salazarismo e tendo-se tornado crescentemente céptico e desiludido, foi-se sentindo gradualmente empurrado para a oposição. Nos círculos literários e artísticos em que se movia, esse cepticismo e essa desilusão, quando não a oposição aberta, eram dominantes. É sabido que em princípios de 1935 rompeu de forma pública com o Estado Novo, apesar de recém-premiado pelo governo de Salazar pela sua obra poética nacionalista Mensagem. A concessão desse prémio literário visava abertamente aliciar o premiado para a posição de poeta-profeta do regime. A reacção de Pessoa a esta tentativa de aliciamento foi a publicação do artigo "Associaçóes Secretas" em defesa da Maçonaria, a inimiga máxima do regime e então ameaçada por um projecto de lei que preconizava a sua extinção. Apesar da censura, o autor conseguira habilmente fazer estampar o artigo com grande

\footnotetext{
${ }^{37}$ BNP/E3, 92E-58r, em Fernando Pessoa, Sobre o fascismo.
} 
destaque no Diário de Lisboa $^{38}$. A última gota nesse processo de ruptura total ocorreu semanas depois, na sequência do discurso de Salazar na festa de entrega dos prémios literários, a que o premiado Pessoa não compareceu. No seu discurso, Salazar permitiu-se fazer não só o elogio da censura como também da imposição de "directrizes" políticas aos escritores e aos artistas, apelidando os intelectuais renitentes de "sonhadores nostálgicos do abatimento e da decadência” - uma frase que parecia talhada para atingir pessoalmente o poeta que rompera semanas antes com o regime. A fúria que Pessoa teve ao ler o discurso nos jornais ficou registada em vários dos seus escritos e até em poemas satíricos que escreveu, ridicularizando o ditador. Um desses poemas, de que andaram cópias dactilografadas pelos cafés, era assinado, precisamente, por um "Um sonhador nostálgico do abatimento e da decadência”.

Numa carta que então escreveu ao presidente Carmona (e que nunca enviou), Pessoa evocava o episódio do discurso de Salazar, acusando este de, com a inútil pretensão de impor directrizes à arte, ter enxovalhado todos os escritores portugueses, "muitos deles seus superiores intelectuais" e de ter, de um só golpe, afastado de si "o resto da inteligência portuguesa que ainda o olhava com uma benevolência já um pouco impaciente e uma tolerância já vagamente desdenhosa" ${ }^{39}$. E numa carta inacabada a Adolfo Casais Monteiro, escrita um mês exacto antes de morrer, numa altura em que vira artigos seus sobre a invasão italiana da Etiópia rejeitados pela censura, Pessoa acrescentava isto:

Ficámos sabendo, todos nós que escrevemos, que estava substituída a regra restritiva da Censura, "não se pode dizer isto ou aquilo", pela regra soviética do Poder, "tem que se dizer aquilo ou isto". Em palavras

\footnotetext{
${ }^{38}$ Ver Barreto (2011).

${ }^{39}$ Publicado pela primeira vez em Cunha (1987).
} 
mais claras, tudo quanto escrevermos, não só não tem que contrariar os princípios (cuja natureza ignoro) do Estado Novo (cuja definição desconheço), mas tem de ser subordinado às directrizes traçadas pelos orientadores do citado Estado Novo. ${ }^{40}$

$\mathrm{Na}$ verdade, os motivos que afastaram Pessoa do salazarismo foram, em boa parte, os mesmos que sempre o tinham feito rejeitar o fascismo mussoliniano. A diferença, explica o escritor nos trechos citados, estava em que a ditadura portuguesa não fora desde o início propriamente uma tirania, como Pessoa sustenta ter sido o caso da italiana. Quando a liberdade de expressão em Portugal - e, particularmente, a do próprio Fernando Pessoa - se viu completamente agrilhoada, cedendo o lugar ao discurso único dos totalitarismos, o escritor tirou as suas conclusões definitivas.

${ }^{40}$ Martines (1998), p. 282 
BIBLIOGRAFIA:

BARRETO, José (2007), "Fernando Pessoa racionalista, livre-pensador e individualista: a influência liberal inglesa", Jeronimo Pizarro e Steffen Dix (coord.), A arca de Pessoa: novos ensaios, Lisboa, ICS.

(2009), "Fernando Pessoa e a invasão da Abissínia pela Itália fascista", Análise Social, 44, 193, pp. 693-718.

(2011), "A História do artigo 'Associações Secretas", Fernando Pessoa, Associaçôes Secretas e outros escritos, Lisboa, Ática, pp. 239-288.

(2012a), "Mussolini é um louco: uma entrevista desconhecida de Fernando Pessoa com um antifascista italiano", Pessoa Plural, 1, Primavera $<$ http://www.brown.edu/Departments/Portuguese_Brazilian_Studies/ ejph/pessoaplural/Issue1/PDF/I1A06.pdf>.

(2012b), "A publicação de $O$ Interregno no contexto político de 1927-1928", Pessoa Plural, 2, Outono <http://www.brown.edu/Departments/Portuguese_Brazilian_Studies/ejph/pessoaplural/Issue2/PDF/ I2A06.pdf>.

CABRAL, Manuel Villaverde (1983), "O pensamento político de Fernando Pessoa”, Revista de Livros do Diário de Notícias, 2-3, pp. I, VI-VII e X.

(2000) "A estética do nacionalismo: modernismo literário e autoritarismo político em Portugal no início do século XX”, N. S. Teixeira, A. C. Pinto, A Primeira República portuguesa: entre o liberalismo e o autoritarismo, Lisboa, Colibri.

CAETANO, Marcelo (1926), "Arte sem moral nenhuma", Ordem Nova, 4-5, Junho-Julho, pp. 156-158.

COELHO, Jacinto Prado (1975), "Comentário a 'Sobre as posições políticas de Fernando Pessoa’ de Alfredo Margarido”, Colóquio. Letras, 23, Janeiro, p. 68.

CUNHA, Teresa Sobral, João Rui de Sousa, org. (1985), Fernando Pessoa: o último ano, Lisboa, Biblioteca Nacional.

CUNHA, Teresa Sobral (1987), "Fernando Pessoa em 1935. Da ditadura e do ditador em dois documentos inéditos", Colóquio. Letras, 100, Novembro, pp. 123-131.

DE CUSATIS, Brunello (2005), Esoterismo, mitogenia e realismo político em Fernando Pessoa, Porto, Caixotim.

GENTILE, Emilio (2006), Politics as Religion, Princeton, Oxford, Princeton University Press. 
LOPES, Teresa Rita, coord. (1993), Pessoa inédito, Lisboa, Livros Horizonte. MARGARIDO, Alfredo (1971), "La pensée politique de Fernando Pessoa", Bulletin des Études Portugaises, 32, pp. 141-184.

(1975), "Sobre as posiçōes políticas de Fernando Pessoa", Colóquio. Letras, 23, Janeiro, pp. 66-68.

(1983), "Futuristas e nacional-socialistas", JL Jornal de Letras, Artes e Ideias, 68, 27-9, p. 21.

(1983), "Pessoa, ídolo dos nacional-sindicalistas", JL Jornal de Letras, Artes e Ideias, 73, 29-11, pp. 4-5.

(1984) "Nota curta para lembrar que Pessoa admirou Mussolini”, JL Jornal de Letras, Artes e Ideias, 85, 21-2, p. 11.

(1985), "Pessoa: na 'situação' ou na 'oposição'?", JL Jornal de Letras, Artes e Ideias, 177, 26-11, p. 17.

(1986), Introdução a Fernando Pessoa, Santo António, São João, São Pedro, org. Alfredo Margarido, Lisboa, A Regra do Jogo, pp. 9-90.

MARTINES, Enrico, ed. (1998), Cartas entre Fernando Pessoa e os Editores da "presença", Lisboa, IN-CM.

MORODO, Raúl (1997), Fernando Pessoa e as "revoluçôes nacionais" europeias, Lisboa, Caminho.

PESSOA, Fernando (1979a) Sobre Portugal. Introdução ao problema nacional, org. Joel Serrão, Lisboa, Ática.

(1979b), Da República, org. Joel Serrão, Lisboa, Ática.

(1980), Ultimatum e páginas de sociologia politica, org. Joel Serrão, Lisboa, Ática.

(2006), Poesia 1931-1935 e não datada, ed. Manuela Parreira da Silva et al., Lisboa, Assírio e Alvim.

(2011), Associaçôes Secretas e outros escritos, ed. José Barreto, Lisboa, Ática.

PINTO, António Costa (1996), "Modernity versus Democracy? The Mystical Nationalism of Fernando Pessoa", Zeev Sternhell, The Intellectual Revolt Against Liberal Democracy 1870-1945, Jerusalem, The Israel Academy of Sciences, pp. 343-355.

PROENÇA, Raul (1926), O Fascismo, separata de "O fascismo e as suas repercussōes em Portugal", Seara Nova, 77, 6-3.

VEIGA, Pedro (1982), Afinidades políticas, religiosas e filosóficas entre Fernando pessoa e a Renovação Democrática, Porto, Centro Editorial Português. 